ENCYCLOPEDDIE Encyclopédie berbère

BERBERE

1 | 1984

1 | Abadir - Acridophagie

\title{
Abū l'Hasan
}

(Voir Mérinides)

C. Agabi

\section{OpenEdition}

\section{Journals}

Édition électronique

URL : http://journals.openedition.org/encyclopedieberbere/798

DOI : $10.4000 /$ encyclopedieberbere.798

ISSN : 2262-7197

\section{Éditeur}

Peeters Publishers

\section{Édition imprimée}

Date de publication : 1 novembre 1984

Pagination : $90-91$

ISBN : 2-85744-201-7

ISSN : $1015-7344$

\section{Référence électronique}

C. Agabi, « Abū l'Hasan », Encyclopédie berbère [En ligne], 1 | 1984, document A27, mis en ligne le 01 décembre 2012, consulté le 05 octobre 2020. URL : http://journals.openedition.org/ encyclopedieberbere/798; DOI : https://doi.org/10.4000/encyclopedieberbere.798

Ce document a été généré automatiquement le 5 octobre 2020.

(c) Tous droits réservés 


\title{
Abū l'Hasan
}

\author{
(Voir Mérinides)
}

\section{Agabi}

1 Le plus puissant des sultans mérinides qui régna vingt ans (1331-1351) et faillit réaliser sous sa domination l'unité du Maghrib. Son activité belliqueuse se tourne d'abord contre le royaume 'abd-el-wadide mais il dut abandonner l'expédition contre Tlemcen en raison de la rébellion de son frère Abū 'Ali, maître de Sijilmassa. Abū l'Hasan replace le Tafilalet sous la domination mérinide, ainsi que le Sous qu'il soumet grâce aux Arabes Ma'qil. Maître du Maghreb extrême il peut s'intéresser davantage aux affaires d'Espagne, venant au secours des Naçrides une fois de plus bousculés par les Castillans. Abū l'Hasan s'empara de la ville des Zyanides (1337) et poursuivit sa progression vers l'Est. Ayant rompu avec les Hafsides après la mort de son beau-père 'Abū Bakr, il marche sur Tunis dont il s'empare en septembre 1347. C'est l'apogée du règne et de la puissance mérinide mais dès l'année suivante les revers graves se multiplient ; vaincu par les Arabes révoltés et encerclé dans Kairouan, il rejoint difficilement Tunis. Au même moment, son fils Abu 'Inan se fait proclamer à Tlemcen qu'il abandonne bientôt aux 'Abd el-Wadides revenus en force. Les trois années que Abu l'Hasan devait continuer à vivre ne sont qu'une succession d'échecs de plus en plus graves: abandonnant Tunis et son rêve de reconstituer l'empire almohade, le sultan, revenant par mer fait naufrage près de Bougie, après avoir reconstitué une partie de ses forces à Alger en gagnant l'appui des Arabes Sowaïd, il marche contre Tlemcen mais il est vaincu dans la plaine du Chélif. S'étant réfugié à Sijilmassa, il s'efforce de reconstituer une partie de sa puissance en contrôlant le Tafilalet mais il est abandonné par ses alliés Sowaïd. Poursuivant sa marche vers l'Ouest il s'établit à Marrakech et marche contre $A b \bar{u}$ 'Inan, mais celui-ci sort vainqueur de la rencontre qui se fit sur les bords de l'Oum er-Rebia. Réfugié chez les Hintata du Haut-Atlas mais cerné par les troupes de son fils, $A b \bar{u}$ l'Hasan finit par capituler et abdique en faveur d'Abū 'Inan. Il mourut peu après chez les Hintata (mai 1351) mais son fils fit transporter son corps dans la nécropole mérinide de Chella.

2 Cette triste fin de doit pas faire oublier l'importance de son règne et les qualités de ce fastueux monarque. Il avait été surnommé «le Sultan noir» car il était fils d'une 
Ethiopienne. Très pieux, il connaissait par cœur une grande partie du Coran; soucieux de rendre la justice, il sollicitait les avis de ses conseillers et ordonna de nombreuses constructions à Fès.

\section{BIBLIOGRAPHIE}

Voir Mérinides.

INDEX

Mots-clés : Biographie, Maghreb, Maroc, Moyen Âge 